\title{
University Teachers' Information Literacy and Its Training under the Background of Education Information
}

\author{
Yanfeng Chen ${ }^{1, a}$ \\ ${ }^{1}$ College of Mathematics, Tonghua Normal University Jilin Province, China \\ awenjianke2007@163.com
}

\begin{abstract}
Keywords: Information literacy; University teachers; Education information; Information technology education; Ability
\end{abstract}

\begin{abstract}
Information literacy not only includes the use of the contemporary information technology to quickly obtain information, efficient processing and processing information, to create the basic skills of information transfer, but also is the creation of the new environment in the modern information technology, the attitude and awareness of independent learning, critical spirit and strong sense of social responsibility and sense of participation. University teachers should have the ability of information processing, information exchange, problem solving ability and information ability and so on. University teachers with good information literacy is the need of information technology development, is their own needs, is the need for future teaching methods reform, is the need to continue education. To cultivate the information literacy of university teachers, we should start from the following aspects: changing ideas, setting up the modern education idea, increasing investment, optimizing the teaching environment of modern education, improving teachers' application of information technology, developing the knowledge structure of the teachers' compound knowledge, strengthening the teachers' training and improving the ability of teachers' network retrieval.
\end{abstract}

\section{Introduction}

With the development of multimedia computer and network communication technology in the field of education, education from the target to the content, from the process to the method, from the strategy to the means, and no one is not a profound change. Information literacy has become an important part of College Teachers' comprehensive quality, how to effectively improve the information literacy of teachers has become an important issue in the higher education field. The teacher's information literacy training must be based on the full understanding the concept and connotation of information literacy.

\section{University Teachers Should Have the Information Literacy}

The term "information literacy" was first proposed by President Paul Zerkowski of the American Information Industry Association in 1974, he said: "only the people who have been trained in the use of information resources can be called a person with information literacy. They have mastered the technology and ability to use a variety of information tools, and can find information to form a solution to solve the problem." Information literacy has been defined since 1974, and its definition is constantly changing. With the development of society and technology, people have different understanding, experienced a focus on mastering the information technology, with information awareness, to have the ability to select and evaluate the information and to lay the foundation for lifelong learning. To emphasize the cultivation of "information literacy", we should regard the information literacy comprehensively.

Information Processing Capability. Information processing capacity is also known as the information selection and processing capabilities, usually including: the ability of the literature search, the use of tools, the development of network resources, the use of multimedia courseware production and application ability, etc.. These should be the essential information processing ability of the 
modern university teachers. In today's society, the rapid development of science and technology, the rapid development of knowledge, teachers shoulder the important task of inheriting culture, serving the society and cultivating talents[1].

Information Communication Skills. Information exchange is "in the communication between people and people through the symbol transmission of information, ideas, attitudes, feelings and other phenomena". Human society in the system of the existence and development, people in this society are in a variety of ways to carry out information exchange all the time, it can be said that the information exchange is the main condition of human society, if there is no information exchange, human society will stop running, the rigid demise. The traditional teaching method is the unidirectional exchange that one teacher talk, all student listens to the teacher. Information technology increases the number of channels of communication between teachers and students, in addition to the direct exchange of teachers and students, but also increased the "students - information technology tools - teachers" such a communication channels, such as Fig. 1.

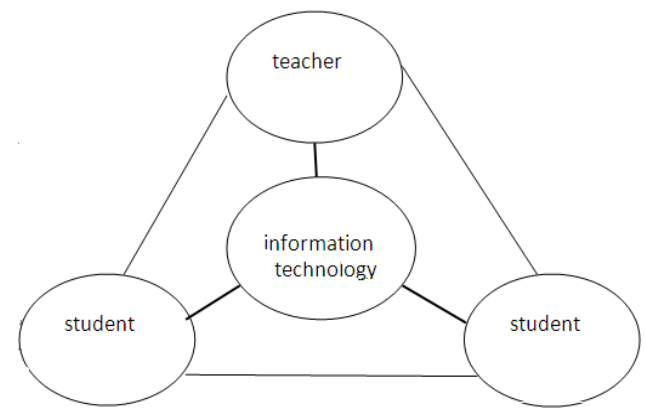

Figure 1. Teachers and students exchange under the influence of information technology

Problem Solving Skills. The connotation of "problem solving" is to identify information problems or information needs, select information strategies, search and access to information, to organize and classify information, integrate information and construct the problem. In the social sense of information technology, it is only by combining information technology with various kinds of problems in social activities to display its great value. Left the problem solving, information technology will lose the sense. The first aspect is to find the problem[2]. Einstein once said: "it is more important to ask questions than to solve the problem. The latter is the process of the method and the experiment, but the problem is the key to the problem". In the teaching of college teachers, we should encourage and guide the students to think and ask questions. And then put forward the solution of the information problem, see Table 1.

Table 1 Big6 Skills

\begin{tabular}{|c|c|}
\hline 1.task determination & $\begin{array}{l}1.1 \text { identify tasks (or information problems) } \\
1.2 \text { to determine the information required to complete a task (or } \\
\text { solve a problem). }\end{array}$ \\
\hline $\begin{array}{l}\text { 2.strategy for searching } \\
\text { information }\end{array}$ & $\begin{array}{l}2.1 \text { discuss all possible sources of information } \\
2.2 \text { select the most appropriate source of information }\end{array}$ \\
\hline 3.retrieval and acquisition & $\begin{array}{l}3.1 \text { search information source } \\
3.2 \text { to find information in information sources }\end{array}$ \\
\hline 4.the use of information & $\begin{array}{l}4.1 \text { in information sources, through reading, listening, } \\
\text { observation, touch and other ways to feel the information } \\
4.2 \text { filter out information }\end{array}$ \\
\hline 5.integrate & $\begin{array}{l}5.1 \text { organize information from a variety of information sources. } \\
5.2 \text { show and express the organization information. }\end{array}$ \\
\hline 6.evaluate & $\begin{array}{l}6.1 \text { evaluation learning process (efficiency) } \\
6.2 \text { evaluation learning outcomes (effectiveness) }\end{array}$ \\
\hline
\end{tabular}

Note: Big6 skills are designed to develop the information literacy, based on the critical thinking of the information problem solving system solutions. 
Information Judgment. Information society has made people ( in real life ethics and laws and regulations) in the virtual world has been a severe challenge. University teachers should have the ability to judge the corresponding information, information ethics and morality has to adapt to the information age, familiar with relevant laws and regulations, establish a model of information ethics and the law for the students[3]. University teachers should not only improve their own information ethics moral level and legal awareness, but also to teach students, improve the students' moral level of information ethics and legal awareness. Activities and communication is the foundation of students' Ideological and moral formation, this kind of activity and communication, teachers' behavior, it will have a subtle effect on students'.

\section{Education Information Requires Teachers Should Have Good Information Literacy}

University Teachers Have Good Information Literacy is the Need for the Development of Information Technology. With the coming of information age, information is becoming an important resource. With the rapid development of information technology, multimedia and network technology, the human production, life style, thinking mode and learning style have a great impact on information technology development. The development of information technology has made people's learning and communication break the boundaries of the past. It has brought new space for the improvement of human ability. With the emergence of the new teaching media group, the teaching concept and the learning concept of the information teaching environment has changed greatly, the students' learning style has changed, the students' learning autonomy and the individuality are becoming more and more. Along with teaching reform, information technology application in teaching has become the most important topic. It is a good way to take advantage of information technology and actively carry out network teaching in school daily teaching. It is a good way to carry out quality education and health education. It will make outstanding contributions to talents training in the information age[4].

University Teachers Have Good information Literacy is their Own Needs. The information age calls for the whole nation to strengthen the information literacy education, as the teachers and knowledge transfer, the teacher should first have a comprehensive information literacy. The teaching work of university teachers will focus on the full use of network resources and all kinds of information resources to support students' autonomous learning, and put more emphasis on information technology teaching in the teaching process of high school students learning. Information technology has been in the same position with the teachers for the teaching authority. At the same time, the new curriculum idea, curriculum structure and evaluation method are a new challenge to the university teachers. These challenges are reflected in the concept of education, the teaching habits, the new teaching situation, the knowledge reserve, the information technology and the new learning style. In the information environment, a high quality university teachers should have the modern teaching ideas, teaching ideas, to grasp the modern teaching methods, skilled use the information tools to collect, organize and use the information resources, and through the network to communicate with students, in a subtle educational environment to cultivate students' information awareness.

University Teachers Have Good Information Literacy is the Need for the Future Teaching Methods Reform. Former Soviet educator B.b.J.Ki once said: "the most important and most difficult problem in the optimization procedure of the teaching method is to choose a variety of teaching methods and make it reach the best teaching effect in the limited time." The trend of the modern teaching method is mainly reflected in two aspects: on the one hand, the individual activities as an important part of the teaching process, focusing on individual adaptation and student participation. Compared with the traditional method, the time of student's individual activity time increased obviously, the student becomes the master of study, but no longer is the passive recipient[5]. On the other hand, the development of modern teaching media such as TV, video, CD, network and so on, provide a new development space, the conditions of the interaction between teachers and students become more and more diversified, so that students in the knowledge, ability, interest, expertise and 
personality traits and other aspects of adaptive development become possible. In the daily teaching, because of the influence of the traditional teaching form (explanation, demonstration, practice) and the limitation, it makes the teaching objective single, monotonous, and the learning content is closed. Such teaching has killed the students' individuality and creativity. Modern education attaches great importance to the development of human personality, the use of artificial intelligence technology combined with cognitive psychology to build up the intelligent tutoring system, can be based on the different cognitive styles and needs students to help, so that students learn from the past to the group of non population, and not the group learning can fully reflect the students personality.

University Teachers Have Good Information Literacy is the Need to Continue Education. With the rapid development of science and technology in the information age, knowledge is updated at an unprecedented speed, and professional life has changed frequently. People need to learn to adapt to the rapid changes in the information age. They can adapt to the survival and development of the information age. The "one-time education for life" concept has been unable to meet the requirements of the times, can not meet the social development demand for new talents, only continuous learning, in order to speed the era of survival, development and success. University teachers can not only rely on the knowledge and ability to meet the needs of the present and future work, the university teachers must continue to receive education, and constantly update their knowledge structure, so that they have the opportunity to understand the latest trends in the development of the discipline[6].

\section{Cultivate the Teachers Information Literacy in University}

Change Ideas, Establish Modern Education Idea. Educational information process is not the introduction of information machine and information technology, but the process of transforming educational ideas and educational ideas. Network is not only learning the media, but also learning resources, learning has become an indispensable part of people's daily life. College teachers should abandon the old traditional teaching ideas, establish modern educational ideas, cultural ideas, ethics, aesthetic concepts, time and space concepts, and the benefits of the information age. All departments should be combined with the characteristics of higher education, extensive and in-depth education information policies, laws and regulations, moral education based on the development of China's education information construction, so that every university teacher can profoundly understand the specific requirements of modern education and teachers in the information era, so as to cultivate their modern education consciousness, concept, knowledge, ability and ethics, so as to meet the needs of educational information[7,8].

Increase Investment, Construct the Optimization of Modern Education Teaching Environment. The teaching environment of the modern education includes two parts, hard environment and soft environment. In contrast, the latter is more important, even with the most modern equipment, thinking, working and learning or a traditional set of modern equipment. At present, the development of college teaching information technology is lagging behind, the formation of this situation is the cause of many aspects, in addition to the university teachers themselves, the school is one of the main reasons for the lack of attention. In this regard, the relevant departments of universities should increase the investment, provide the corresponding software and hardware conditions for teaching departments, teachers have the "useless", to support and promote the development of higher education information. We should also pay attention to the construction and enrich the relevant teaching materials of various disciplines, to provide digital resources. In the construction of teaching environment resources, the software and hardware should be paid equal attention and $\mathrm{CO}$ construction. All kinds of software resources including media material, teaching case, teaching software, network course, literature, common problem solving, resource directory index, etc.. In the process of modern education technology teaching, in addition to use their own design and development or purchase audio-visual materials, also should make full use of the campus network, the Internet and other media. Therefore, the "optimization" technology and equipment 
environment should be the best combination of various technical means under the conditions of existing material and teachers[9].

Improve Information Skills Application, Cultivate Compound Type Knowledge Sincerely Structure. With information network expansion and education information development, the quality of teachers in the first line of work in universities put forward higher requirements, the role of college teachers should be the "information source" into "controller". University teachers as students thinking and shape ability, if not have certain information literacy, it is difficult to adapt to the needs of the education information, it is not to grasp the latest results and the latest methods in time, will greatly affect the teaching quality and teaching effect. In the Internet age, information technology is generally involved in the teaching process and partly replaced by the teachers, with the best adaptability of the complex structure teachers. Universities should provide a variety of opportunities to strengthen the cultivation of teachers in order to develop innovative ability including learning ability, scientific research ability, interpersonal skills, psychological adjustment ability and organizational management capabilities of the composite structure, to learn to use the network knowledge and computer network technology as the core of modern education technology, so that they grasp the multimedia network teaching and development skills, improve their teaching ability and the ability of network curriculum development. University teachers can provide learning information consultation and guidance by using the application software, the development the teaching materials, the combination of the teaching materials, the methods of the combination module structure, the theory and method of artificial intelligence.

Strengthen Teacher Training, Improve the Teachers' Network Retrieval Ability. Teacher training is the need of the individual growth and the overall development of the school teachers, and the teachers should be trained in a variety of forms. Teachers' active participation, the training and education teaching practice and teachers' research activities are closely integrated, which aims to promote teachers' professional development and improve the school's overall school level. This is an important guarantee for the teachers to seize the frontier knowledge of discipline. For teachers to fulfill the old role, complete the new conversion role and promote teaching style formation, these have a positive and practical significance. Teacher training should focus on the content and practicality, emphasizing the flexibility and diversity in the method. In addition to pay attention to strengthen their professional moral cultivation, the university teachers should pay special attention to the new technology, new theory, new project, new pattern and new educational technology[10]. Quickly grasp the modern education ideas, to understand the advanced knowledge of the disciplines, and to penetrate into the teaching, improve teaching quality, teaching efficiency. The university library should provide the teachers with high efficiency, and it is necessary to make good cooperation between the two parties. So the library should strengthen the training of teachers' network information retrieval ability, the training form can be used to do training courses, seminars, etc., including the database contents and CD-ROM search method, search and download network resources, literature, network communication methods, etc..

In short, the cultivation of teachers' information literacy is an important cornerstone of education, train teachers' high degree awareness, correct attitude, skills, and the ability to use modern education information technology and comprehensive application of information, is the historical responsibility of College teachers in the new period.

\section{References}

[1] H.J.Pin, To improve the teachers quality in ethnic minority areas under the background of educational information, Education Explore (2013)100-101.

[2] L.D.Mei,On the promotion of teacher information literacy, Electronic Test(2013)206-207.

[3] Z.G.Yong, The education information should focus on the teacher's quality,China Education Newspaper, 2012-09-21. 
[4] J.Z. Song,On the new requirements of the educational information and the teachers' quality, Education Research(2005)82-83.

[5] P.X. Yang, F.G. Quan, Y.H. Liang,From primary and secondary school education information to talk about teachers' literacy promotion, Education Information(2003)59-60.

[6] S. J. Wei,To enhance the teachers information literacy under the education information, Asia Pacific Education(2015)145.

[7] X.F.Tang,Professional literacy development of university teachers under the background of educational information, Journal of Ezhou University (2015)86-88.

[8] Z. Yan, L.Y. Li, The cultivation of teachers under the education information, Education Theory and Practice(2015)38-40.

[9] Z. W. Wei, D.R. Li,Analysis on the Vocational College Teachers' ability to improve teachers ability in the perspective of educational information technology,Education and Occupation(2015)64-66.

[10]F.M.Jian, Universitiy teachers faculty information literacy and its cultivation in education informatization, Human Resources Management(2014)125-128. 